\title{
CHANGES IN RURAL POVERTY AFTER POLAND'S ACCESSION TO THE EUROPEAN UNION
}

\author{
Barbara Chmielewska $^{1 \bowtie}$, Józef Stanisław Zegar ${ }^{1}$ \\ ${ }^{1}$ Institute of Agricultural and Food Economics - National Research Institute, Poland
}

\begin{abstract}
The purpose of this paper is to assess changes in the risk of poverty in European Union Member States and the extent of poverty in rural areas and farming households after Poland's accession to the EU. The above aspect was considered against the background of urban residents and other socioeconomic groups of households. The study was based on EU-SILC, Eurostat and CSO data. For a comparative assessment across EU countries, the poverty and/or social exclusion risk index was used. For a comparative assessment of rural and urban areas, the following basic poverty thresholds (as estimated by the Central Statistical Office), were used: extreme poverty (subsistence minimum), relative poverty and statutory poverty. Despite the high level of socioeconomic development in the European Union, the risk of poverty or social exclusion is widespread and varies strongly across countries, regions and social groups. In Poland, rural areas are more affected by poverty than urban areas, mainly because rural households have lower incomes than urban households. The risk of poverty in the EU has declined. After the accession to the EU, Poland has experienced a decrease in the extent of poverty. This positive change was the combined result of many factors, mainly including an increase in incomes of the farming and rural population. In Poland, income disparities between rural and urban residents and between farm and landless families have decreased. Reducing poverty and social exclusion is one of the most important goals of the EU social policy.
\end{abstract}

Keywords: poverty thresholds, income, rural areas, city, diversification

\section{INTRODUCTION}

Initially, poverty meant only the absence of financial resources necessary to meet the basic needs. Gradually, this concept has been extended to cover cases where an individual is unable to assume his/her life functions due to social and personal circumstances. It was recognized that human beings themselves should be able to choose the goods and services they use according to their individual needs, skills and customs of the country, region or community where they live (Panek et al., 1999; Panek and Zwierzchowski, 2013). Therefore, poverty means the absence of sufficient financial resources necessary to meet the basic needs, and the inability for an individual, family or community to use available goods and services at a level acceptable in their environment.

Despite the high level of socioeconomic development in the European Union, poverty and social exclusion are widespread and vary strongly across countries, regions and social groups. Rural areas are more affected by poverty than urban areas, mainly because rural households have lower incomes than urban households.

\section{MATERIAL AND METHODS}

The purpose of this paper is to assess changes in the risk of poverty in European Union Member States and the extent of poverty in rural areas and farming households after Poland's accession to the EU. The above aspect was considered against the background of urban

\footnotetext{
PhD hab. Barbara Chmielewska, prof. IERiGŻ-PIB, General Economics Department, Institute of Agricultural and Food Economics - National Research Institute, Świętokrzyska 20 St., 00-002 Warszawa, Poland, e-mail: chmielewska@ierigz.waw.pl; https://orcid.org/0000-0003-1609-4809
}

(C) Copyright by Wydawnictwo Uniwersytetu Przyrodniczego w Poznaniu 
residents and other socioeconomic groups of households. The study was based on EU-SILC, Eurostat and CSO data.

For a comparative assessment across EU countries, the poverty and/or social exclusion risk index was used. A fundamental indicator of the population's socioeconomic situation in EU Member States, it consists of three sub-indicators representing the percentage of people: (1) at risk of relative poverty (after social transfers), (2) affected by severe material deprivation and (3) living in households with very low work intensity ${ }^{1}$.

For a comparative assessment of rural and urban areas and across socioeconomic groups of Polish households, the extent of economic poverty was used, as estimated by the Central Statistical Office based on the following poverty thresholds: extreme poverty (subsistence minimum), relative poverty and statutory poverty ${ }^{2}$. The extent of poverty is reflected in the percentage of people living in households whose expenditure (also including the value of products received free of charge and the value of natural consumption) was below the defined poverty threshold.

\footnotetext{
${ }^{1}$ People at risk of poverty are those living in households whose disposable income (after social transfers) is below the poverty threshold set at $60 \%$ of the median equivalized income. People affected by severe material deprivation are those who declare to be unable to satisfy (due to financial reasons) at least 4 out of 9 defined material needs. People living in households with very low work intensity are persons aged 0-59 living in a household whose adult members aged 18-59 were employed for less than $20 \%$ of their potential full working time during the reference year. The total number of people at risk of poverty or social exclusion is lower than the total number of people affected by any of the three forms of poverty or social exclusion as some persons are affected by more than one of these situations at a time (Downward trend..., 2017; Podstawowe dane..., 2017). All nine material needs are specified in these publications.

${ }^{2}$ Subsistence minimum, calculated by the Institute of Labor and Social Studies (ILSS), takes into account only those needs which cannot be addressed at a later time. Consumption below this level causes a biological emaciation. The relative poverty threshold is set to $50 \%$ of the average total household expenditure. The extent of poverty is primarily assessed with an indicator referred to as the poverty rate, i.e. the percentage of people living in households whose expenditure (including the value of products received free of charge and the value of natural consumption) was below the defined poverty threshold. The statutory poverty threshold is determined by the amount which, pursuant to the Social Welfare Act, entitles the affected individuals to apply for cash benefits under social welfare system (Zasięg ubóstwa..., 2015).
}

Poverty is also assessed based on the subjective poverty line for a particular type of households. The subjective poverty line corresponds approximately to the level of income the respondents believe to be "barely sufficient." It is determined based on assessments of household incomes declared by the respondents as barely sufficient and necessary to "make ends meet."

\section{STUDY RESULTS}

\section{Changes in the risk of poverty in rural areas in Poland and other EU countries}

When joining the European Union, Poland was in the group of countries exhibiting the highest risk of poverty and social exclusion in rural areas. In 2005, more than half of rural residents $(50.6 \%, 8,814$ thousand people) belonged to this category. The urban population was at a lower (though also high) risk of poverty. The same year in Poland, as many as $47.2 \%$ (2,302 thousand people) of small city residents and $38.6 \%$ (5,965 thousand people) of big city residents were at risk of poverty or social exclusion. After the accession, the risk of poverty declined in almost all EU-13 countries, both in the countryside and in cities. By 2016, the percentage of people at risk of poverty in Poland decreased to $28 \%$ in rural areas, to $16 \%$ in big cities, and to $19 \%{ }^{3}$ in small towns (Fig. 1).

The variation in the risk of poverty between rural areas and cities has its origin in income disparities between rural areas and cities. The equivalized disposable income in rural areas is lower than in cities. This is true for almost all European Union Member States, except for Luxembourg, United Kingdom, Ireland, Czech Republic and Estonia where rural incomes were higher than urban incomes in 2016. Income disparities between rural areas and big cities are greater than between rural areas and small towns; with the increase in the country's wealth, these income gaps are narrowing, though at a relatively slower pace in the EU-15 than in EU-13 countries (Fig. 2, 3). The most significant changes have

\footnotetext{
${ }^{3}$ According to the new classification, three categories of units are identified: (1) cities, (2) towns and suburbs and (3) rural areas. Cities: at least $50 \%$ of the population live in densely populated grid cells; towns and suburbs: less than $50 \%$ of the population live in rural grid cells; rural areas: more than $50 \%$ of the population live in the countryside. Grid cell: a unit used to calculate the population density (A harmonised definition..., 2014). This study used the following names: cities: big cities, towns and suburbs: small cities, rural areas: rural areas.
} 


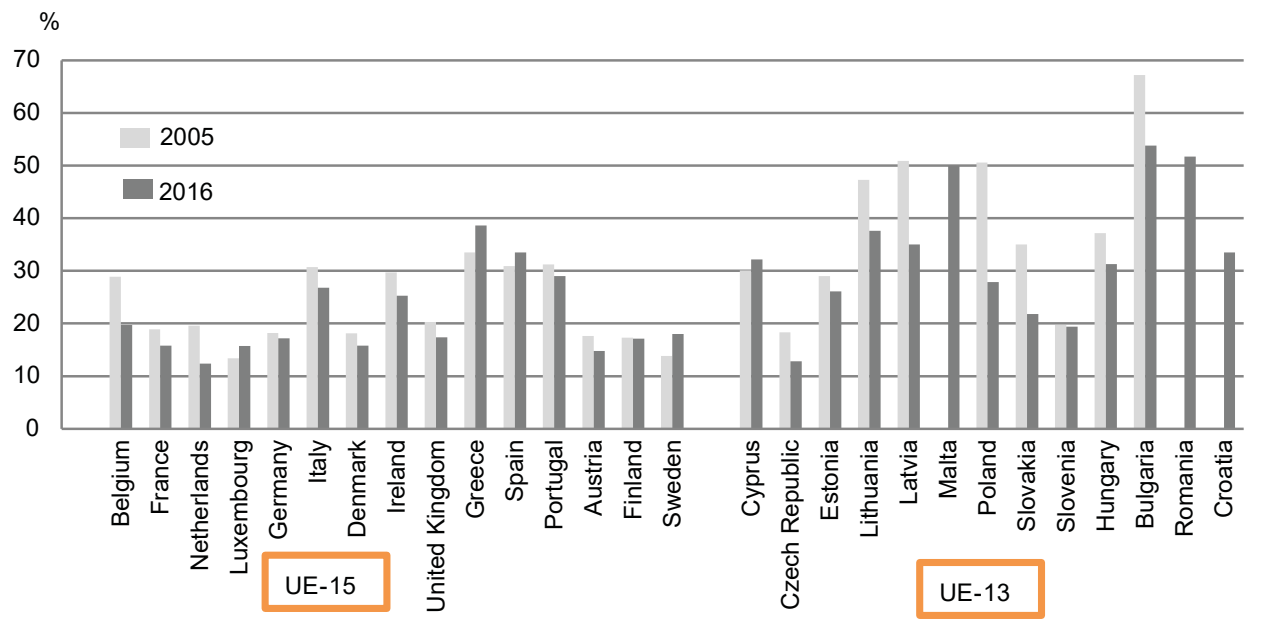

Fig. 1. Risk of poverty and social exclusion in rural areas in EU Member States in 2005 and $2016(\%)$

Source: Eurostat data.

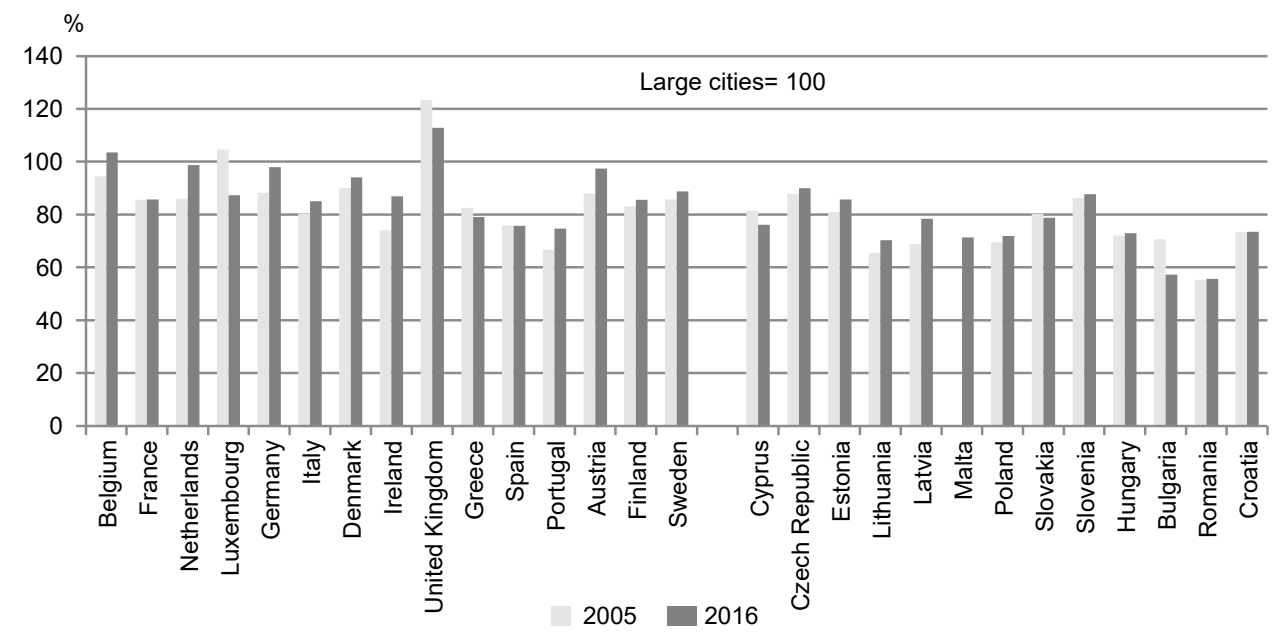

Fig. 2. Ratios of rural household incomes* to big-city household incomes in European Union countries $(\%)$

*Household's equivalized disposable income; Bulgaria: as at 2006; Romania: as at 2007; Croatia: as at 2010 .

Source: Eurostat data.

been recorded in the Netherlands, Germany, Austria, Portugal, Latvia, Lithuania, Slovakia and Bulgaria.

In Poland, after the accession, the rural/big-city household income ratio increased from $70 \%$ to $72 \%$, while in the case of small cities it decreased from $88 \%$ to $83 \%$. In most countries, the reduction in income disparities between rural and urban residents was mainly due to a much higher income growth in rural than in urban areas. In Poland, from 2005 to 2016, the equivalized disposable income increased by $122 \%$ in rural areas, i.e. slower than in small towns $(137 \%)$ but faster than in big cities (115\%). 


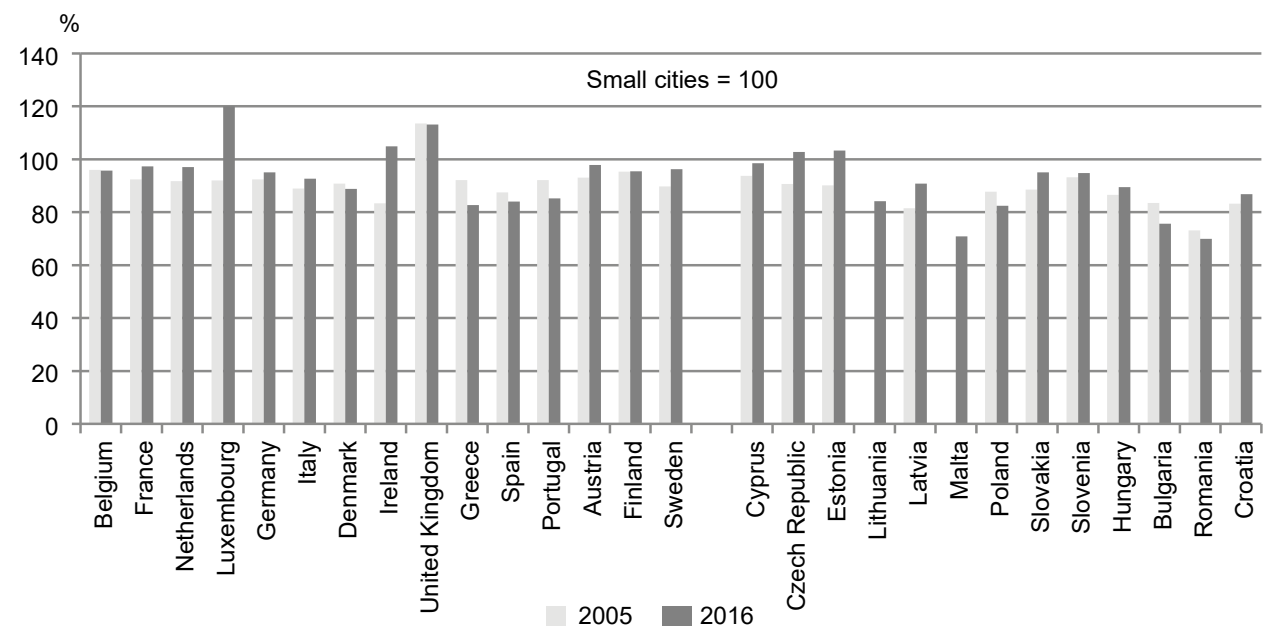

Fig. 3. Ratios of rural household incomes* to small-town household incomes in European Union countries $(\%)$

*Household's equivalized disposable income; Bulgaria: as at 2006; Romania: as at 2007; Croatia: as at 2010 .

Source: Eurostat data.

\section{Extent of economic poverty in Polish households}

After integration into the EU, Poland experienced a significant reduction in the extent of economic poverty, with persistent gaps between rural and urban households and across socioeconomic groups of households (Table 1, Fig. 1).

In Poland, between 2005 and 2016, the percentage of all households members living in extreme poverty (with expenditure below the subsistence minimum) decreased from $12.3 \%$ to $4.9 \%$ (from $18.7 \%$ to $8.0 \%$ in rural areas and from $8.2 \%$ to $2.9 \%$ in cities). Despite the subsidies, transfers and growing incomes, the percentage of persons living in farmers' households decreased slightly, namely from $18.1 \%$ to $11.0 \%$. Similarly, the percentages measured with other poverty indicators (relative and statutory thresholds) were higher in rural areas than in cities, and so were the corresponding decline rates.

The 2005-2016 period witnessed a decline in poverty but this was not a permanent process (Fig. 4). In the first years after the crisis, despite a rise in income levels, improvement in housing conditions and better availability of durable goods, the extent of poverty increased. This is because the improvements were not evenly distributed across the society. This led to a situation where economic poverty, with all its consequences, continued to be an important social problem in Poland (Ubóstwo w Polsce..., 2015).

Poverty continues to be higher in the countryside than in cities. In 2005, the extent of extreme poverty in rural areas was 2.3 times higher than in urban areas. After 11 years, the discrepancy ratio rose to 2.8 , confirming the progressive economic stratification of rural areas. The biggest differences in the extent of poverty exist between rural areas and the largest cities (with a population of 500,000 or more).

The extent of poverty also varies by household type, i.e. the number of children in the family. The post-accession period was characterized by a decrease in poverty in families bringing up children. A particular improvement was recorded in 2016, especially in large families who experienced the highest decline in the percentage of people living in a household with expenditures below the extreme poverty threshold (in families with at least 4 dependent children, the percentage dropped from $43.5 \%$ in 2005 to $14.0 \%$ in 2016 , while in families with 1 child the corresponding decline was from $5.5 \%$ to $1.7 \%$ ). Despite the improvement, larger families continue to be more affected by poverty. In 2005, the extent of extreme poverty affecting married couples with 4 or more children was almost 8 times higher than in the case of those with 1 child. After 11 years, this ratio decreased 
Chmielewska, B., Zegar, J. S. (2018). Changes in rural poverty after Poland's accession to the European Union. J. Agribus. Rural Dev., 4(50), 355-365. http://dx.doi.org/10.17306/J.JARD.2018.00442

Table 1. Extent of poverty affecting Polish households in 2005-2016

\begin{tabular}{|c|c|c|c|c|c|c|c|c|c|c|c|c|}
\hline \multirow{3}{*}{ Specification } & \multicolumn{12}{|c|}{ Members of households with expenditure below (\%) } \\
\hline & \multicolumn{4}{|c|}{ extreme poverty threshold } & \multicolumn{4}{|c|}{ relative poverty threshold } & \multicolumn{4}{|c|}{ statutory poverty threshold } \\
\hline & 2005 & 2014 & 2015 & 2016 & 2005 & 2014 & 2015 & 2016 & 2005 & 2014 & 2015 & 2016 \\
\hline Total & 12.3 & 7.4 & 6.5 & 4.9 & 18.1 & 16.2 & 15.5 & 13.9 & 18.1 & 12.2 & 12.2 & 12.7 \\
\hline \multicolumn{13}{|c|}{ Socioeconomic groups of households } \\
\hline Farmers & 18.1 & 12.1 & 14.7 & 11.0 & 26.4 & 28.0 & 28.9 & 26.5 & 28.2 & 21.2 & 25.2 & 25.8 \\
\hline Employees & 11.2 & 6.5 & 5.6 & 3.9 & 16.9 & 15.2 & 14.4 & 12.5 & 17.3 & 11.9 & 11.7 & 11.9 \\
\hline Self-employed & 6.3 & 4.1 & 3.1 & 2.2 & 10.2 & 8.9 & 8.9 & 8.3 & 10.6 & 6.8 & 7.0 & 8.1 \\
\hline Old-age pensioners & 6.3 & 5.8 & 5.0 & 3.9 & 10.1 & 12.1 & 11.4 & 10.9 & 8.5 & 7.2 & 7.3 & 8.0 \\
\hline Disability pensioners & 17.5 & 12.5 & 10.7 & 8.5 & 25.6 & 25.5 & 23.2 & 21.8 & 23.1 & 17.8 & 15.9 & 16.9 \\
\hline $\begin{array}{l}\text { Recipients of non-wage } \\
\text { benefits }\end{array}$ & 29.9 & 21.1 & 17.9 & 15.9 & 38.5 & 36.2 & 36.1 & 31.6 & 40.1 & 29.9 & 30.3 & 30.6 \\
\hline \multicolumn{13}{|l|}{ Place of residence } \\
\hline Rural areas & 18.7 & 11.8 & 11.3 & 8.0 & 27.0 & 24.4 & 24.0 & 20.8 & 27.3 & 18.7 & 19.8 & 19.7 \\
\hline Cities in total & 8.2 & 4.6 & 3.5 & 2.9 & 12.5 & 11.0 & 10.0 & 9.5 & 12.3 & 8.0 & 7.4 & 8.2 \\
\hline $\begin{array}{l}\text { including: with a population } \\
\text { below } 20,000\end{array}$ & 5.4 & 8.5 & 5.4 & 4.0 & 19.0 & 18.8 & 14.5 & 11.3 & 12.4 & 13.4 & 10.6 & 9.3 \\
\hline 500,000 or more & 1.0 & 1.0 & 1.1 & 1.1 & 3.8 & 3.4 & 3.3 & 4.5 & 1.9 & 2.3 & 2.2 & 3.6 \\
\hline
\end{tabular}

Source: compilation based on Sytuacja..., 2007; Ubóstwo w Polsce..., 2015; Zasięg ubóstwa..., 2017.

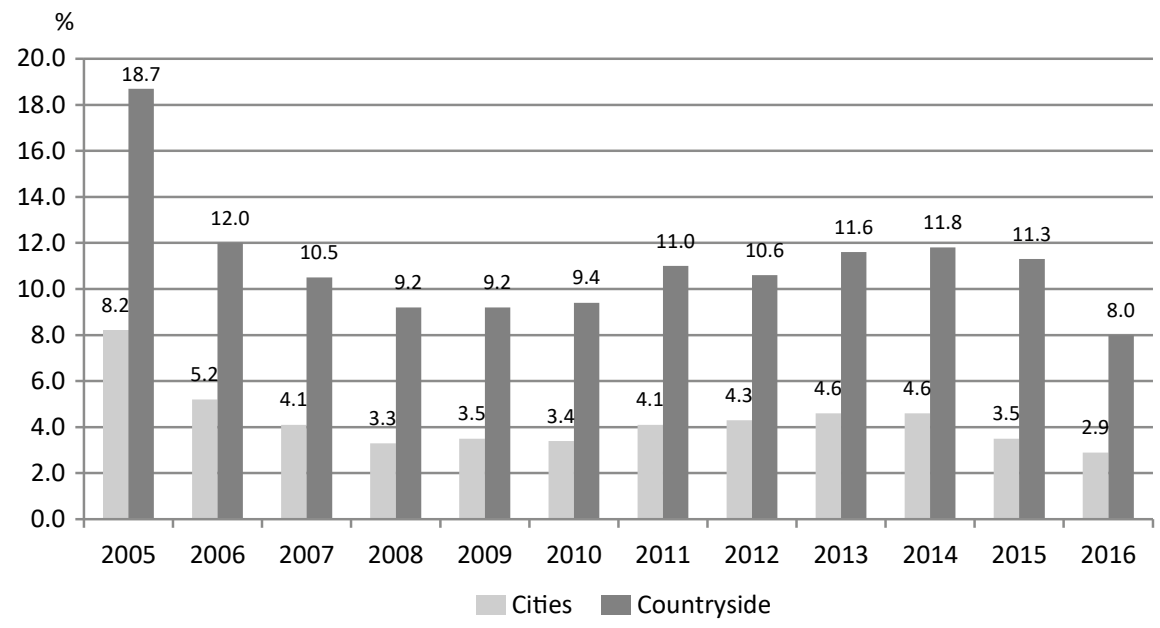

Fig. 4. Extent of extreme poverty in the rural and urban areas in 2005-2016

Source: compilation based on Sytuacja..., 2007; Ubóstwo w Polsce..., 2015; Zasięg ubóstwa..., 2017. 


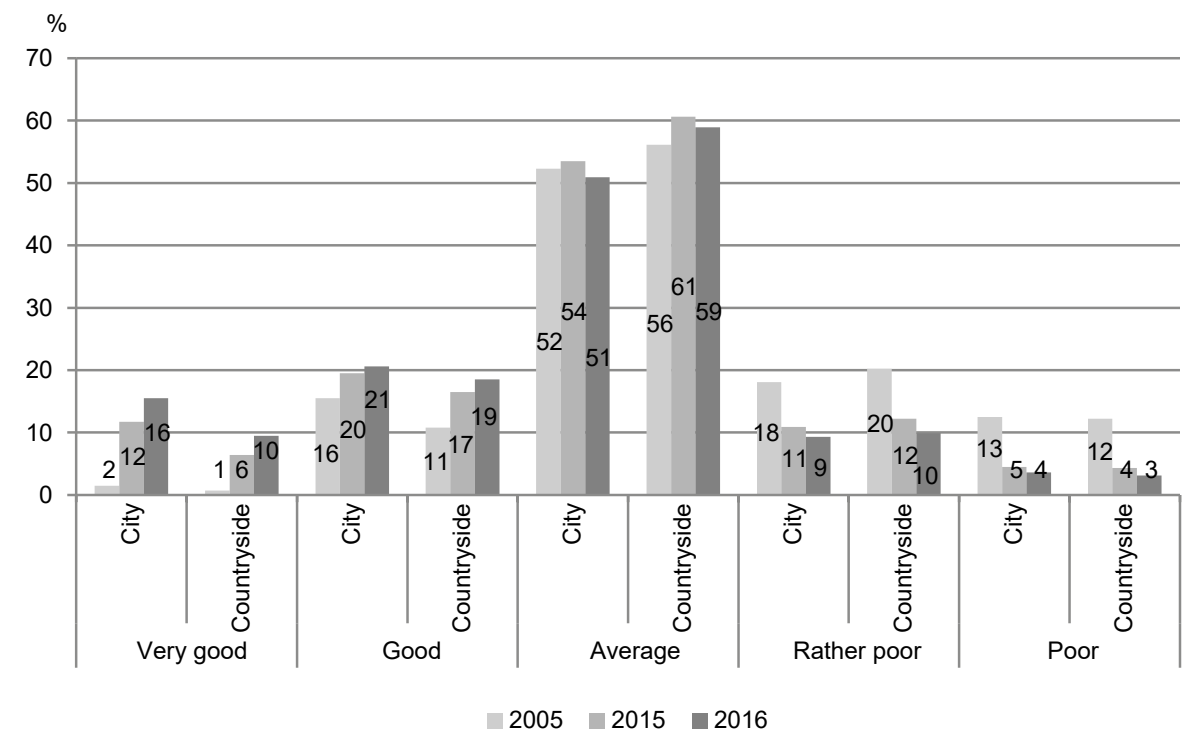

Fig. 5. Subjective rating of financial situation of households by location class ( $\%$ of households)

Source: compilation based on Sytuacja społeczno-ekonomiczna..., 2017.

to slightly more than 5 (Sytuacja..., 2007; Ubóstwo w Polsce..., 2015; Zasięg ubóstwa..., 2017).

The reasons for the reduction in poverty across all types of households, especially in large families, include the launch of the " $500+$ " program 4 .

In addition to the three basic poverty indices referred to above, there is a new indicator, based only on household expenditure: the sphere of deprivation ${ }^{5}$. The rural

${ }^{4}$ The Family 500 plus program (in place in Poland since April 1, 2016), is a government program intended to help families in bringing up their children through monthly parental benefits in an amount of PLN 500 for the second and each subsequent child in the family. The benefit for the first child depends on meeting the income criterion. The program's normative basis is the Act of February 11,2016 on state aid in bringing up children (Journal of Laws of 2017, item 1851).

${ }^{5}$ The household (and thus all of its members) is considered to be affected by deprivation if the level of its expenditure (including the value of products received free of charge and the value of natural consumption) is below the threshold of the sphere of deprivation, determined based on the social minimum calculated by the ILSS (the social minimum is considered to be the limit of the "minimum decent standard of living" below which people face deprivation of inherent human needs); this limit is about twice the threshold of extreme poverty determined based on the subsistence minimum (Ubóstwo w Polsce..., 2015). population is more affected by deprivation than urban people. The percentage of people living in households suffering from deprivation decreases as the number of residents increases, reaching the lowest level in the largest cities. In 2015, 42.7\% of people living in Polish households suffered from deprivation; for the urban population, that ratio was $33.8 \%$ (varying in the range of $44.8 \%$ in cities with a population below 20,000 to $18.1 \%$ in cities with a population of 500,000 or more). In the countryside, as many as $56.5 \%$ of household members experienced deprivation. Over the past four years, there has been a weak upward trend in the extent of deprivation in rural areas and in the largest cities, whereas a downward trend has been observed in other cities (Sfera niedostatku..., 2016).

The analyses of the extent of poverty also consider the subjective rating of the households' financial situation by rural and urban residents as well as by the households. In 2005-2016, there were more "very good and good" ratings and less "rather poor and poor" ratings (Fig. 5). In rural areas, the percentage of "very good and good" ratings is clearly lower, the percentage of "average" ratings is higher, while the percentage "poor and rather poor" ratings is similar in urban and rural areas. Generally, it can be concluded that rural residents, 
especially farmers, have slightly lower aspirations and, consequently, give their financial situation a higher subjective rating than it may result from the absolute amounts of income ${ }^{6}$. Undoubtedly, in the case of farmers' households, the use of farming assets to produce food products for the household (consumer self-supply) can be vital in avoiding extreme poverty.

The subjective rating of the financial situation varies significantly between socioeconomic groups of households. Households who rely on self-employment outside agriculture were the most satisfied with their financial situation. Of all socioeconomic groups of households, this group had the highest percentage (58\% in 2016) of "very good and good" ratings and the lowest percentage $(4 \%)$ of "rather poor and poor" ratings. Also, most households in this group (13.7\% in 2015) indicated their current income to be enough to easily "make ends meet." Farmers rated their financial situation much lower, with $28 \%$ of "very good and good" ratings and $24 \%$ of "rather poor and poor" ratings. Also, $64.7 \%$ of the farmers' households believe their current income makes it difficult to "make ends meet" whereas much less (27.5\%) declare to "make ends meet" quite easily (Dochody..., 2017; Sytuacja społeczno-ekonomiczna..., 2017).

\section{Income as a basic agent of change} in the extent of poverty affecting households The basic agent of change in the extent of poverty, as stated above, is household income. In Poland, in recent decades, lower levels of agricultural labor profitability have been recorded. Given that the socioeconomic structure of rural areas is dominated by farmers and agriculture, the above has a significant impact on the income of the rural population. Fewer and fewer people find employment in agriculture, and thus the number of families (households) who earn their living in agriculture is decreasing. In this context, the rural farming population seeks employment in non-agricultural sectors which provide them with higher incomes than agriculture. A large group of rural residents also live off of social security and social welfare.

The accession to the European Union supported the direct creation of jobs in rural areas. As a result,

${ }^{6}$ As indicated by a comparative analysis of proportions between per capita income in cities and in rural areas; by the percentage of individual categories of ratings; and by a similar analysis of individual socioeconomic groups of households. incomes of the rural population grew faster than those of urban residents, including people living in the largest cities. However, in absolute terms, rural residents earn less than urban dwellers. In 2005-2016, the nominal per capita income of rural and urban residents rose by $105 \%$ and $89 \%$, respectively. Interestingly, the income of residents of small cities (with a population of up to 20,000 ) increased by $101 \%$, while in the largest cities (with a population of 500,000 or more) by $84 \%$, i.e. 21 percentage points less than in rural areas. The real income rose by ca. $80 \%$ for rural residents and by ca. $50 \%$ for urban residents (ca. $60 \%$ for the smallest towns and ca. $40 \%$ for the largest cities). Because rural incomes grew faster, there was a slight reduction in income disparity between the countryside and cities. Rural incomes differ most from urban incomes and are most similar to incomes of residents of the smallest towns. On the other hand, the persistent large gap in income between big cities an rural areas is largely due to three reasons. Firstly, big cities are home to institutions and economic operators who offer higher pay rates but also require higher levels of education from their employees. Secondly, lower levels of education of rural residents impinge on the lower employability in well-paid professions. The percentage of the population with a tertiary education in rural areas, in cities and in the largest cities is $12 \%$, $28 \%$ and $43 \%$, respectively (Dochody..., 2017). Thirdly, the number of members of an average rural family is higher than of an urban family (3.1 to 2.4 as at 2016) (Budżety..., 2017), and the percentage of large families is also higher in rural areas.

In the post-accession period (2004-2016), per capita income of rural households grew more than twice in nominal terms, with the fastest rise being recorded in income from employment (2.9 times) and in income from non-agricultural self-employment (2.7 times). Incomes from social benefits grew at a slower pace (almost 1.8 times); the lowest growth rate was recorded for farm incomes (1.5 times). There was a particularly large rise in incomes from other benefits (such as parental allowances and benefits, including those disbursed under the 500+ program). In 2004-2015, these benefits increased only by $12 \%$; on the other hand, they grew 2.4 times in 2016 over 2015 as a consequence of payments under the $500+$ program which contributed to a significant improvement in the economic situation of many rural families. 
The relatively slower growth of incomes from social benefits is caused by the reduced number of beneficiaries and the way social benefits are revalued. The number of individual farmers covered by the social security system decreased from 1,645 thousand in 2005 to 1,194 thousand in 2016 (while the number of people covered by the non-agricultural social security system increased from 7,524 thousand to 7,715 thousand). During this period, the average monthly pensions grew slower for individual farmers than for non-farmers (52\% vs. $69 \%)$ (Rocznik Statystyczny..., 2017).

Farming incomes grew faster than in other socioeconomic groups of households. This confirms that after the accession, a key role was played by factors driving an increase in farming incomes, notably including various forms of financial support under the Common Agricultural Policy (CAP) dedicated to the agri-food sector, farms and rural areas. In the EU, Poland became a leader in the implementation of the rural development program. In the post-enlargement era, an average farm made significant economic and social progress. However, many farms, especially small ones, have continued to experience problems in improving their income situation. Significant support for these farms is delivered through the CAP; funds are allocated not only directly to farmers ${ }^{7}$ but also to rural areas, because rural investments drive the creation of new jobs allowing to supplement farm incomes with non-agricultural incomes.

Faster growth of incomes of rural and small town residents was undoubtedly determined by a better income situation of farmers, reinforced with funds provided under the Common Agricultural Policy mechanisms. In $2005-2016$, farming incomes rose by $113 \%$, i.e. faster than in an average household (an increase by 101\%) and even faster than in households run by people selfemployed outside agriculture (rise by $92 \%$ ).

When considering the higher growth rates of farming incomes, three circumstances must be taken into account. Firstly, in the pre-accession period, there was a significant gap in incomes between the farmers' households and other socioeconomic groups; after the accession, this disparity decreased slightly. Secondly, agricultural income fluctuates strongly depending on harvests and the economic situation. After several lean

${ }^{7}$ In $2005-2016$ total subsidies to agriculture increased by $125.4 \%$; the share of subsidies in agricultural incomes increased from $46.4 \%$ to $49.8 \%$ (EAA, Eurostat). years, 2016 was a good year for agriculture. Thirdly, there is a statistical trap relating to the criterion used to identify the farmers' households (a dominant share of incomes from agricultural activities ${ }^{8}$ ). In 2004-2016, there was a negligible increase in the total number of households; the number of households which include a holder of an individual farm decreased by $19 \%$ while the number of farmers' households decreased by $23 \%$. It can be presumed that most weaker farms (with lower incomes) "fell out" of the group of farmers' households. Households which include a holder of an individual farm accounted for 39\% of rural households in 2004 and for $32 \%$ in 2016 , including $14 \%$ and $11 \%{ }^{9}$ of farmers' households, respectively. The latter accounted for ca. $18 \%$ and $12 \%$ of the rural population, respectively. It follows from the above that farmers' households (and, in general, households which include a holder of a farm) have a diminishing impact on the income situation of rural residents.

The contribution of various sources of income to the budget of a rural family (including farm holders) has evolved for many years. The importance of income from employment and self-employment increases while that of income from agricultural work and non-wage benefits decreases. In 2016, the income mix of rural households was as follows: income from employment accounted for $48.5 \%$ ( $54.8 \%$ in cities), income from self-employment ${ }^{10}$ contributed $7.2 \%$ ( $9.0 \%$ in cities), and income from an individual farm had a share of $9.3 \%$ ( $0.4 \%$ in cities). Social benefits continue to significantly contribute to household budgets, with a share of $31.9 \%$ and $30.8 \%$ in the total income of rural and urban households, respectively. Characteristically, in rural areas, "overall benefits" include a much higher percentage of "allowances and other parental benefits" than in cities $(14 \%$ vs. $7 \%)$. This is mainly related to the greater number of children in rural families.

The importance of different sources changes over time; and the accession to the European Union created

\footnotetext{
${ }^{8}$ In statistics, a farmer household is defined as one whose income is dominated $(>50 \%)$ by income from agricultural activities carried out in the farm.

${ }^{9}$ On a countrywide basis, these ratios were $4.8 \%$ and $3.6 \%$, respectively.

${ }^{10}$ Income from self-employment is the part of income derived from self-employed economic activities outside an individual farm and from liberal professions (...). More in: Budżety..., 2017.
} 


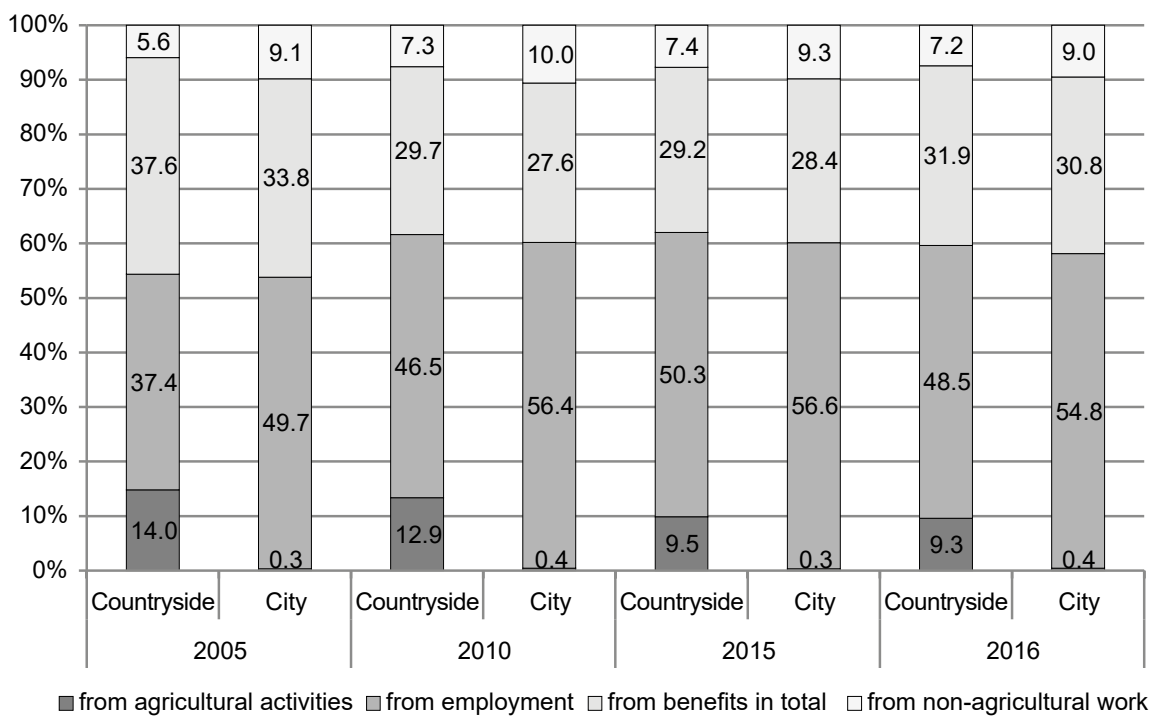

Fig. 6. Structure of average monthly disposable income (in nominal terms) per capita in rural and urban households; grouped by source of income (\%)

Source: own calculations based on Rural-urban diversification, 2013; Socio-economic situation..., 2013; Budżety..., 2017.

a new momentum for this process. While farm incomes and benefits contribute less and less to rural family budgets, incomes from employment and self-employment play an increasingly important role. Urban families saw an increase in the percentage of income from employment with a decrease in income from social benefits. No significant changes have been recorded with respect to other sources. The are significant differences in the income mix between rural and urban households (Fig. 6).

The change in income mix is a consequence of changes in employment structure and, more specifically, of the increased share of individual farms engaged in non-agricultural commercial activities directly related to the farm. Following the integration of Poland into the $\mathrm{EU}$, the share of farms engaged into additional agritourism activities increased the most (from $6.8 \%$ in 2005 to $26.3 \%$ in 2016); the scope of additional activities also includes the processing of agricultural products (an increase from $3.9 \%$ to $6.6 \%$ ) and handicrafts (from $1.6 \%$ to $3.5 \%$ ). This process was enabled by tapping into a niche in those markets (Charakterystyka..., 2006; 2017).

After the accession, Poland saw a revival in agritourism: an alternative source of income for farmers, especially for those with a small area of farmland. This was also supported by the improved economic situation of urban residents, and by a greater inflow of foreign tourists after Poland's accession to the Schengen Area.

\section{SUMMARY AND CONCLUSIONS}

Following Poland's accession to the EU, the risk of poverty and social exclusion decreased, mostly in rural areas. The extent of poverty in households also decreased, and so did the poverty gap between rural and urban residents, and between farm and landless families. A number of factors were involved in these positive developments, primarily including an increase in rural incomes (by $105 \%$ in nominal terms over the $2005-2016$ period, compared to $89 \%$ for urban residents). This is a consequence of multiple processes, including the inflow of EU funds to Polish rural areas, and the number of longterm unemployed being much lower (by 23\%) in the countryside than in cities. However, in terms of income, the rural population still lags behind other groups, especially big city residents. The reasons for these disparities include two factors: firstly, cities (especially big ones) are home to institutions which, while offering good pay rates, require a high level of education from their employees; and secondly, rural residents demonstrate 
lower levels of education than urban residents, and thus have worse employment opportunities in well-paid professions. While a reduction in the extent of poverty will improve the income situation of farm and rural families, it will also require improving the condition of the labor market and the technical infrastructure in rural areas.

\section{SOURCE OF FINANCING}

Institute of Agricultural and Food Economics - National Research Institute, research task PW 2015-2019, No. 4501: Globalne i krajowe uwarunkowania zrównoważonego rozwoju rolnictwa.

\section{REFERENCES}

Budżety gospodarstw domowych w 2016 r. [Household budget survey in 2016] (2017). Warszawa: GUS. Retrieved from (p. 19, 92): https://stat.gov.pl/files/gfx/portalinformacyjny/pl/defaultaktualnosci/5486/9/11/1/budzety gospodarstw_domowych_w_2016.pdf

Charakterystyka gospodarstw rolnych w 2005 r. [Characteristics of farms in 2005] (2006). Warszawa: GUS. Retrieved from (p. 208): https://stat.gov.pl/obszarytematyczne/rolnictwo-lesnictwo/rolnictwo/charakterystyka-gospodarstw-rolnych-w-2005-r-,5,1.html?pdf=1.

Charakterystyka gospodarstw rolnych w 2016 r. [Characteristics of farms in 2016] (2017). Warszawa: GUS. Retrieved from (p. 162): https://stat.gov.pl/obszarytematyczne/rolnictwo-lesnictwo/rolnictwo/charakterystyka-gospodarstw-rolnych-w-2016-r-,5,5.html.

Dijkstra, L., Poelman, H. (2014). A harmonised definition of cities and rural areas: the new degree of urbanisation (p. 5-6). Regional Working Papers. Retrieved from: http://ec.europa.eu/regional_policy/sources/docgener/ work/2014 01 new urban.pdf

Dochody i warunki życia ludności Polski (raport $\mathrm{z}$ badania EU-SILC 2015) [Income and living conditions of the Polish population (report on the EU-SILC 2015 study)] (2017). Warszawa: GUS. Retrieved from (p. 82, 101): https://stat.gov.pl/obszary-tematyczne/warunki-zycia/ dochody-wydatki-i-warunki-zycia-ludnosci/dochodyi-warunki-zycia-ludnosci-polski-raport-z-badania-eusilc-2015,6,10.html

Downward trend in the share of persons at risk of poverty or social exclusion in the EU (2017). Euro. News., 155.

Panek, T., Podgórski, J., Szulc, A. (1999). Ubóstwo: teoria i praktyka pomiaru [Poverty: theory and practice of measurement] (p. 7). Warszawa: SGH.
Panek, T., Zwierzchowski, J. (2013). Porównawcza analiza sfery ubóstwa w krajach UE w ujęciu regionalnym [Comparative analysis of the sphere of deprivation in the EU countries in regional terms]. Zesz. Nauk. Inst. Stat. Demogr. SGH, 35, 8-9.

Podstawowe dane dotyczące zasięgu ubóstwa w Polsce w 2016 r. (wskaźniki monitorujące Krajowy Program Reform na rzecz realizacji Strategii Europa 2020) [Basic data on the range of poverty in Poland in 2016 (indicators monitoring the National Reform Programme for implementing the Europe 2020 Strategy)] (2017). Warszawa: GUS. Retrieved from (p. 2): https://stat.gov.pl/files/gfx/portalinformacyjny/pl/defaultaktualnosci/5487/19/1/1/podstawowe_dane_dotyczace_ubostwa_w_polsce_w_2016.pdf

Program „Rodzina 500 plus” („Family 500 plus” programme) (Dz.U. z 2017 r. poz. 1851). Retrieved from: http://www. program 500plus.pl/terminy-wyplat.html

Rocznik Statystyczny Rzeczypospolitej Polskiej 2016 [Statistical Yearbook of the Republic of Poland 2016] (2016). Warszawa: GUS. Retrieved from (p. 258): https://stat.gov. pl/obszary-tematyczne/roczniki-statystyczne/rocznikistatystyczne/rocznik-statystyczny-rzeczypospolitej-polskiej-2016,2,16.html

Sfera niedostatku w Polsce w latach 2012-2015 - podstawowe dane (na podstawie badania budżetów gospodarstw domowych) [Sphere of deprivation in Poland in the years 2012-2015 - basic data (based on household budget surveys)] (2016). Warszawa: GUS. Retrieved from (p. 5): https://stat.gov.pl/files/gfx/portalinformacyjny/pl/defaultaktualnosci/5487/14/3/1/sfera_niedostatku_2012-2015_ tablice.pdf

Sytuacja gospodarstw domowych w 2006 r. w świetle wyników badań budżetów gospodarstw domowych [Situation of households in 2006 in the light of results of household budget surveys] (2007). Warszawa: GUS. Retrieved from (p. 16): https://stat.gov.pl/obszary-tematyczne/ warunki-zycia/dochody-wydatki-i-warunki-zycia-ludnosci/sytuacja-gospodarstw-domowych-w-2016-r-w-swietle-wynikow-badania-budzetow-gospodarstw-domowych,3,16.html

Sytuacja społeczno-ekonomiczna gospodarstw domowych w latach 2000-2015 [Socio-economic situation of households in the years 2000-2015] (2017). Warszawa: GUS. Retrieved from: https://stat.gov.pl/obszary-tematyczne/ warunki-zycia/dochody-wydatki-i-warunki-zycia-ludnosci/sytuacja-spoleczno-ekonomiczna-gospodarstwdomowych-w-latach-2000-2015-zroznicowanie-miastowies, $5,2 . \mathrm{html}$

Sytuacja gospodarstw domowych w 2016 r. w świetle wyników badania budżetów gospodarstw domowych [Situation of households in 2016 (in the light of results of household 
budget surveys)] (2017). Warszawa: GUS. Retrieved from: https://stat.gov.pl/obszary-tematyczne/warunki-zycia/dochody-wydatki-i-warunki-zycia-ludnosci/sytuacjagospodarstw-domowych-w-2016-r-w-swietle-wynikowbadania-budzetow-gospodarstw-domowych,3,16.html

Ubóstwo w Polsce w latach 2013-2014 [Poverty in Poland in the years 2013-2014] (2015). Warszawa: GUS. Retrieved from (p. 5, 31, 32): https://stat.gov.pl/files/gfx/portalinformacyjny/pl/defaultaktualnosci/5487/1/6/1/ubostwo_w_ polsce_2013_i_2014.pdf

Zasięg ubóstwa ekonomicznego w Polsce w 2015 r. (na podstawie badań budżetów gospodarstw domowych) [Range of economic poverty in Poland in 2015 based on household budget surveys] (2015). Warszawa: GUS. Retrieved from: https://stat.gov.pl/obszary-tematyczne/warunki-zycia/ubostwo-pomoc-spoleczna/zasieg-ubostwa-ekonomicznego-w-polsce-w-2015-r-, 14,3.html

Zasięg ubóstwa ekonomicznego w Polsce w 2016 r. [Range of economic poverty in Poland in 2016] (2017). Warszawa: GUS. Retrieved from (pp. 11-15): https://stat.gov. pl/obszary-tematyczne/warunki-zycia/ubostwo-pomocspoleczna/zasieg-ubostwa-ekonomicznego-w-polsce-w2016-r-, 14,4.html 